\title{
2.5D Crustal Models Derived from Analytical Polynomial Separation Technique and Spectral Analysis of Gravity Data with Their Probable Gold Mineralization Migrations (Batouri, SE-Cameroon)
}

\author{
Ngoumou Paul Claude1*, Assembe Stephane Patrick 2,3*, Owono Amougou Olivier Ulrich Igor4, \\ Meying Arsene', Yandjimaing Justine' ${ }^{3}$, Ngoh Jean Daniel2, Pepogo Man-Mvele Augustin Didier ${ }^{2}$
}

\author{
${ }^{1}$ School of Geology and Mining Engineering, University of Ngaoundere, Meiganga, Cameroon \\ ${ }^{2}$ Postgraduate School of Technology, Science and Geoscience, University of Yaoundé I, Yaoundé, Cameroon \\ ${ }^{3}$ Department of Physics, Faculty of Science, University of Bamenda, Bambili, Cameroon \\ ${ }^{4}$ Department of Physics, Faculty of Science, University of Yaoundé I, Yaoundé, Cameroon \\ Email: *ngpclaude@yahoo.fr, *assembest@yahoo.fr
}

How to cite this paper: Claude, N.P., Patrick, A.S., Igor, O.A.O.U., Arsene, M., Justine, Y., Daniel, N.J. and Didier, P.M.-M.A. (2021) 2.5D Crustal Models Derived from Analytical Polynomial Separation Technique and Spectral Analysis of Gravity Data with Their Probable Gold Mineralization Migrations (Batouri, SECameroon). Advances in Remote Sensing, $10,1-24$.

https://doi.org/10.4236/ars.2021.101001

Received: March 1, 2021

Accepted: March 28, 2021

Published: March 31, 2021

Copyright $\odot 2021$ by author(s) and Scientific Research Publishing Inc. This work is licensed under the Creative Commons Attribution International License (CC BY 4.0).

http://creativecommons.org/licenses/by/4.0/ (c) (i) Open Access

\section{Abstract}

Geophysical surveying is crucial in the investigation of mineral resources in poorly exposed areas such as SE-Cameroon, a region known for its gold mineral potential. In this paper, gravity survey is carried out in the Batouri area, SE-Cameroon based on land gravity data from the Centre-south Cameroon. Therefore, an analytical polynomial separation program, based on least-square fitting of a third-degree polynomial surface to the Bouguer anomaly map, was used to separate the regional/residual components in gravity data. This technique permitted to better understand the disposition of the deep and near surface structures responsible of the observed anomalies in the Batouri area. Spectral analysis and 2.5D modelling of two profiles $\mathrm{P}_{1}(\mathrm{SW}-\mathrm{NE})$ and $\mathrm{P}_{2}(\mathrm{~N}-\mathrm{S})$ selected from the residual anomaly map provided depths to basement. These depths constrain the gravity models along the profiles, indicating a variable thickness of the sedimentary infill with an approximate anomaly of -33 $\mathrm{mGal}$. The 2.5D model of the basement shows a gravity body, with a signature suggesting two close and similar masses, which characterize the quartzbearing formations associated here to granite and gneiss. Our work highlights a main heavy gravity: Gwé-Batouri anomaly, containing the major part of auriferous deposits located along the NE-SW direction. Further, three tectonic sub-basins bounded by normal faults have been highlighted at Guedal, Gwé, and Bélimban, in the south of Guedal-Bélimban depression. They are asso- 
ciated with the extension tectonics, more or less vertical tangential cuts and accidents that have affected the region. A correlation with previous results from tectonic, lithological and gold mineralization activities proves the relevance of the study and the need to intensify geophysical surveying in the area.

\section{Keywords}

Gravity Anomaly, SE-Cameroon, Polynomial Technique, Spectral Analysis, 2.5D Modelling, Gold Mineralization, Batouri Area

\section{Introduction}

The Batouri area (Figure 1(a)) in the SE-Cameroon stretches between $4^{\circ} 00^{\prime}$ and $5^{\circ} 00^{\prime} \mathrm{N}$ latitude, and between $14^{\circ} 00^{\prime}$ and $15^{\circ} 00^{\prime} \mathrm{E}$ longitude. This area located in the southern plateau of Cameroon has a monotonous landscape with the altitude varying from 553 to $885 \mathrm{~m}$. In general, geophysical prospecting enables to infer deep and superficial structures through surface or near-surface measurement of physical variables. In applied geophysics, the gravity method is useful in a reconnaissance or a semi detailed study. Basically, the variations of gravitational field values due to lateral and vertical changes of density, although very small, can be detected and used in order to understand the geology of a given area. As an example, [1] [2] applied gravity inversion and spectral analysis respectively, to characterise granite-greenstone belt areas in Brazil, and to model a sedimentary basin in Cameroon. [3] successfully used gravity study to investigate solid minerals potentialities over the Congo Craton Belt in Cameroon and South West Central African Republic.

A crucial step in gravity investigations is that consisting in removing the effects of deep or shallow structures from the Bouguer anomaly [3] by separating the Bouguer anomaly from individual anomalies (regional and residual anomalies). The regional signal or regional anomaly in the Bouguer map is related to the surrounding and deep structures while the residual anomaly concerns some surface structures as sedimentary layers. There exist many methods to carry out this filtering among which is the analytical polynomial separation technique of gravity anomalies yet to be exploited in this paper. The polynomial approach involving least-squares fitting is less subjective and it enables to better approximate the trend in data even from inaccessible areas, or when data were evenly sampled. Its simplicity and non-computational intensity make it very easy to apply [4] [5] [6] [7]. [8] compiled the available gravity data from the study area. The information from gravity surveys carried out in Cameroon and in the adjacent areas by [8], has been used to infer the structure of the Batouri area in this study (Figure 3(a)). The area comprises the Yaounde domain, the Adamawa-Yade domain, and the West Cameroon domain, corresponding to the Pan-African belt north of the Congo Craton. This current study investigates the 
transition zone North between margin of the North Equatorial Fold or Pan-African Belt (NEFB or PAB) and the Congo Craton (CC) enriched in gold mineralization [9] [10] [11]. Recent regional gravity study including the study area, highlighted N-S, NW-SE, NE-SW, ENE-WSW and WNW-ESE structural features affecting the Panafrican basement, with no clear relationship with in situ gold mineralization [12]. Following this, the aim of this work is to use spectral analysis and 2.5D modelling to estimate the parameters of geological structures of the crust responsible of the observed anomalies along two selected profiles $\mathrm{P}_{1}$ and $\mathrm{P}_{2}$ on the residual map in the Batouri region, Eastern Cameroon. For this purpose, a regional-residual gravity separation of anomalies based on the least squares is initially made, and the results are discussed, taking into consideration the geological knowledge of the region and the modelled mean densities. The intense gold mining in the area will enable to link gravity signatures to gold bearing targets.

\section{Geological and Mining Setting}

Geological mapping of the study area has been done and modified by [12] [13] [14]. The geology of Batouri area (Figure 1(b), Figure 1(c)) comprises formations of the central Cameroon domain affected by the Pan African orogeny. It

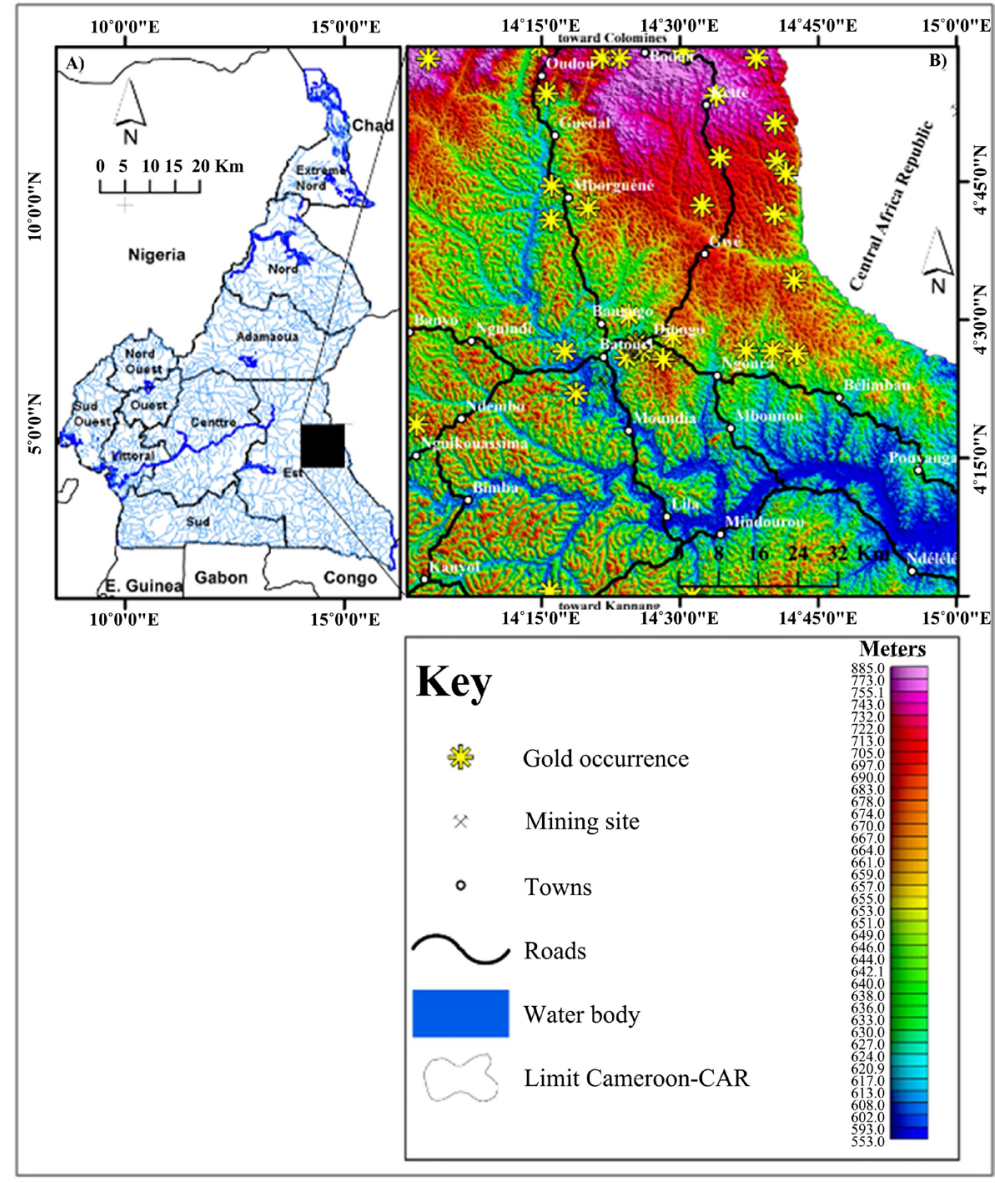

(a)

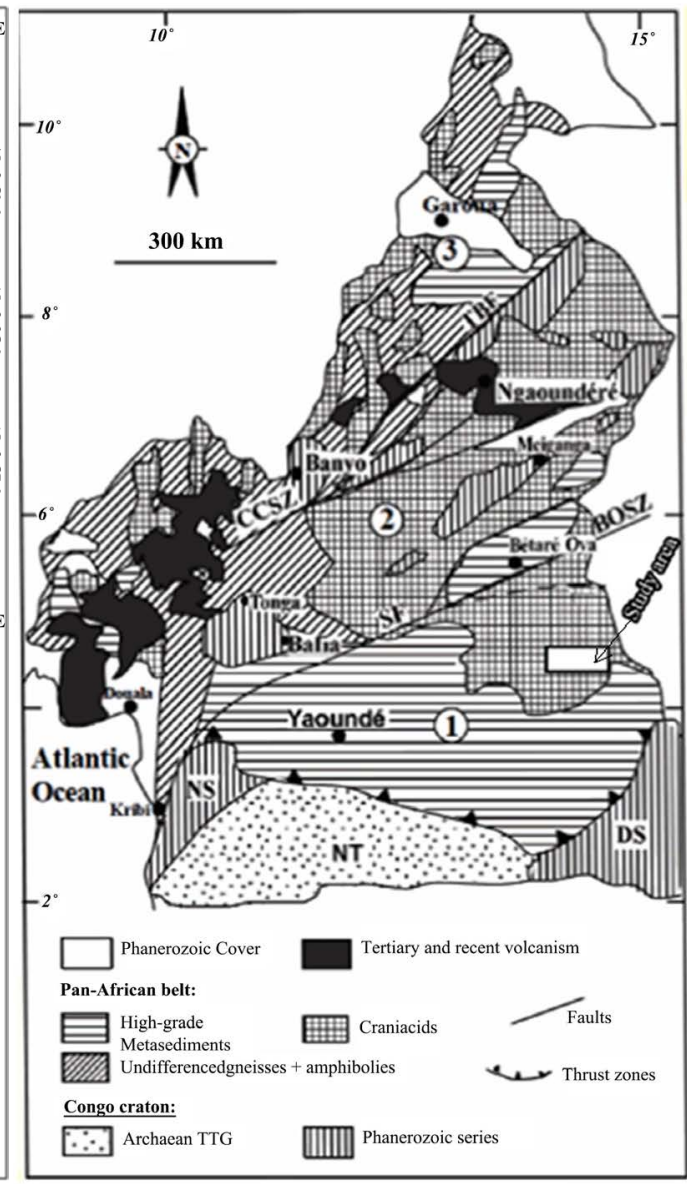

(b) 


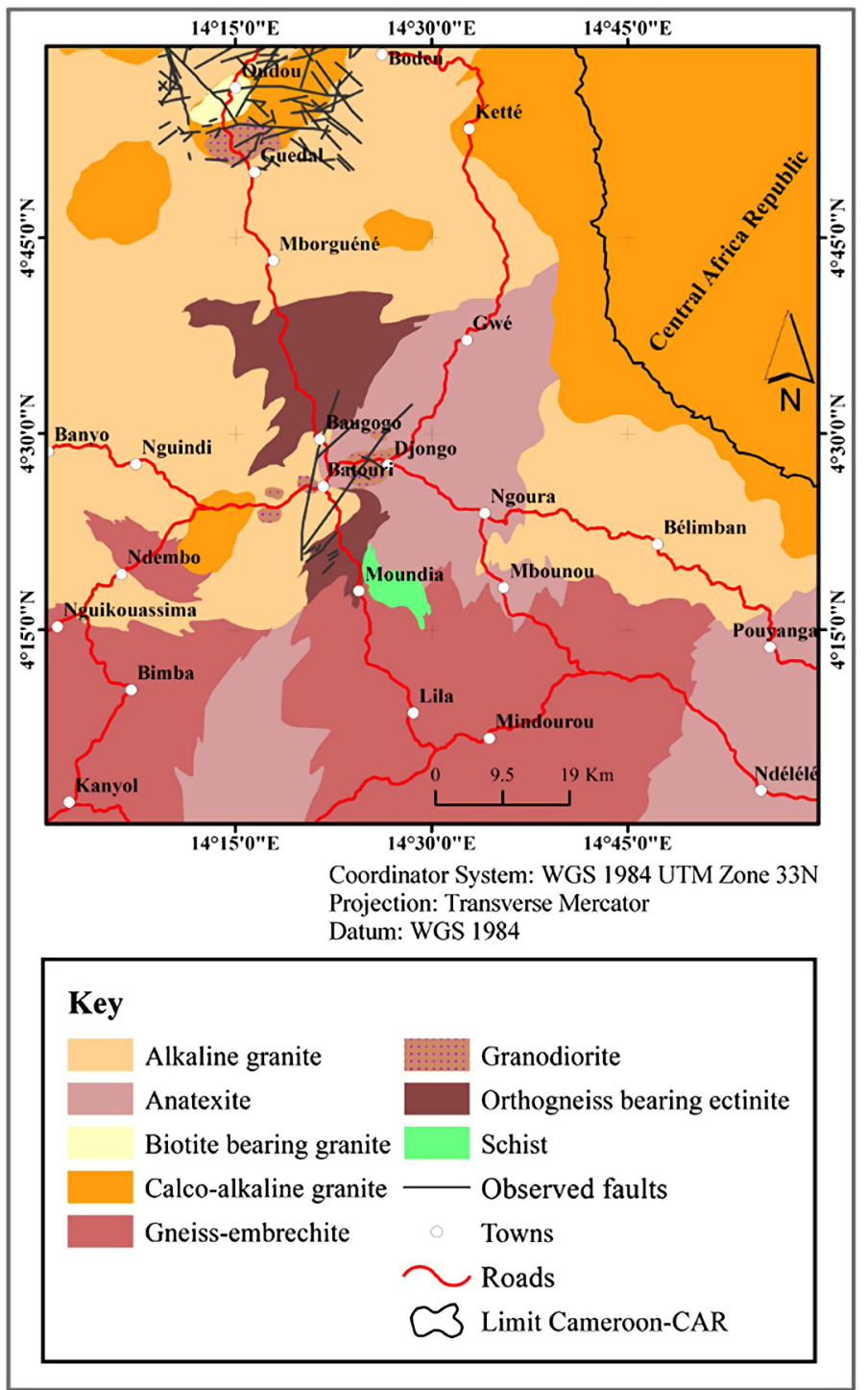

(c)

Figure 1. (a) Location of area of study: (A) Administrative map of Cameroon and with the eastern region of Cameroon; (B) DEM of Cameroon and the study area with the Batouri gold district indicating drainage, gold occurrences and artisanal gold mining sites (modified after [11]). (b) Geological sketch map of Cameroon showing its main lithological domains and the location of the Batouri area: (1) southern domain; (2) central domain; (3) northern domain; BOSZ: Bétaré-Oya Shear Zone; SF: Sanaga Fault; TBF: Tibati-Banyo Fault; NT: Ntem complex; DS: Dja Series; NS: Nyong Series (modified after [33]). (c) Geological map of Batouri area modified (after [13]; Vishiti et al., 2015; [14]).

belongs indeed to the NEFB or Central Africa Orogen with a major link to the Trans-Saharan belt of western African and to the Braziliano Orogen of north eastern Brazil [15]. This belt underlines Cameroon, Chad and the Central African Republic, between the Congo Craton to the south and the western Nigeria shield to the north. [16]-[21] have laid out that the basement in Central Africa consists predominantly of various Precambrian magmatic and metamorphic 
rocks of different stages that outcrop from Cameroon to Sudan. According to geochronologic study [22] [23] [24] [25] [26], Cameroon is made up of two principal structural zones (Figure 1(b)): (1) the Congo Craton in the south and central areas; and the (2) Central Africa Panafrican Belt [20] [21] [27] in north. In Cameroon, the Neoproterozoic realm [28] [29] occurring in the central domain which contains the present study area, is positioned between the Sanaga fault and the Betare-Oya shear zone (BOSZ) to the south and the Tibati-Banyo fault to the north. These large NE-striking transcurrent faults, as well as the Adamawa fault inside the central domain, are regarded as possible prolongations of the major shear zones of NE-Brazil in a pre-drift Gondwana reconstruction [15] [30]. The central domain consists of Archean to Paleoproterozoic high-grade gneisses intruded by widespread Neoproterozoic high-K calc-alkaline syntectonic plutonic rocks [26] [28] [29] [31] [32] [33]. The hosting basement rocks were intensively reworked during a polyphase Pan-African $D_{1}-D_{2}$ deformation associated with amphibolite facies metamorphism.

The rocks of the area (Figure 1(b)) are mainly located in eastern part of central domain. Previous geological investigations have recognized orthogneiss, and rejuvenated granite and migmatite intruded by granitoids during epizonal metamorphism [13] [34] [35] [36]. These granitoids include syn-to post-tectonic granites and granodiorites [35] [36].

From the geological point of view (Figure 1(c)), it is believed that the present structure of the Panafrican belt in Cameroon characterizes a continent-continent collision and post collision of the Congo Craton and the north Cameroon active margins with Archaean-Paleoproterozoic inheritance ([16]). The collision is evident from 1) nappe tectonics along the northern edge of the Congo Craton and the concomitant exhumation of the $620 \mathrm{Ma}$ granulitic rocks believed to have formed at the root of the collision zone. The granulitic belt extends from Cameroon into the Central African Republic. 2) The remobilization and granitization (upwelling of the asthenosphere) that partly affected both landmasses, then, 3) the late development stage of strike-slip faults in central Cameroon as a result of horizontal movements following the multistage collision.

The superficial formations are composed of 1) the eluvium observed in the granitic and gneissic zones south of Batouri; 2) recent alluvium observed in the Kadei valley; and 3) abundant iron or argillite-rich laterites. The Precambrian basement rocks in the region have undergone granitization and migmatization. The granitization yielded syn and post-tectonic granites [37] [38]. The ancient metamorphic series includes ectinites and migmatites, is a set of para and ortho metamorphosed ancient marine sediments. Ectinites in the area include 1) the lower gneisses (biotite, cordierite and sillimanite gneisses) along S-Batouri; 2) the granoblastic and melanocrate amphibolites in NW-Batouri; 3) the crushed secondary quartz-bearing orthogneisses of $\mathrm{N}$-Batouri. migmatites include: 1) diadysites in S-Batouri and similar to frank ectinite with in-fill veins, either inter-stratified or intersecting the shoals; 2) the embrechites observed in the SE-Batouri; and 3) the biotite, amphibole and garnet rich anatexites in the 
SE-Batouri. The above-mentioned metamorphic formations have been traversed by 1) old syn-tectonic heterogenous granitic intrusions (especially found between the south of Batouri, Ndembo, Mborguéné, north of Guedal and in Bélimban); and 2) homogenous late syn-tectonic alkaline granites (found in Bandongoue, Oudou, Ketté and until CAR) with limits sometimes independent of the folds that they overlap in any direction.

Tectonics shows that the basement was intensively reworked during a polyphase Pan-African $D_{1}-D_{2}$ deformation associated with an amphibolite facies metamorphism. The deep folds of the basement are Huronian, in a broad sense. Previous geological investigations have recognized orthogneiss, rejuvenated granite and migmatite intruded by granitoids during epizonal metamorphism [34] [35] [36]. These granitoids include syn-to post-tectonic granite and granodiorite [35] [36]. During and after the orogenies, the whole of the pedestal has played several times, resulting in many fractures of more or less importance sometimes difficult to observe due to the lack of outcrops [13], these forming in the study area a network of NE-SW faults [13].

The Batouri area has been one of the main sites for artisanal gold mining in Cameroon for more than 50 years. [39] estimated the resource potential of the Batouri gold district to be at least 15 tonnes Au. In 2006, African Aura Resources Ltd. acquired the Batouri concession, and exploration pits and boreholes along the host shear zone have yielded high-grade ore samples (as much as $66 \mathrm{~g} \cdot \mathrm{t}^{-1}$ $\mathrm{Au}$ ). The Granitic rocks of Batouri (around Djongo) host U-Pb and Ar-Ar mineralizations including monzogranite-granodiorites formed by differentiation of I-type tonalitic magma under oxidizing conditions in a continental volcanic arc setting [11]. [11] related U-Pb and Ar-Ar mineralizations of Djongo respectively, to the zircon and the alkaline feldspar granite associated to the gold. Batouri granitoïds were emplaced during the collision of the West African Craton and the Congo Craton. The uranium and gold concentrations at the fault intersections rather than along individual faults imply a structural and hydrotherrmalism control of the mineralization [10] [12]. The Batouri gold district is enriched in gold associated with high-grade auriferous quartz veins; gold mineralizations are located on late fractured zones characterized by a major NE-SW shear zone (Figure 1(c)).

\section{Gravity Data}

The current study uses historical data from 54 gravity stations that are part of the dataset collected by ORSTROM in 1995 and [9]. In this work, during the re-digitization of the Bouguer anomaly map of S-Cameroon [9] the portion covering the target area has been and extracted using the Mapinfo $8.5^{\mathrm{TM}}$. These points are separated by a non-regular average distance of $56.3 \mathrm{~km}$ longitude, covering an area of $394.4 \mathrm{~km} \times 307.04 \mathrm{~km}$. Figure 2 (a) shows the distribution of data in the study area. After interpolation by the program we got 690 points on a regular grid step of $13.6 \mathrm{~km}$ longitude. Data within the study area was separated 


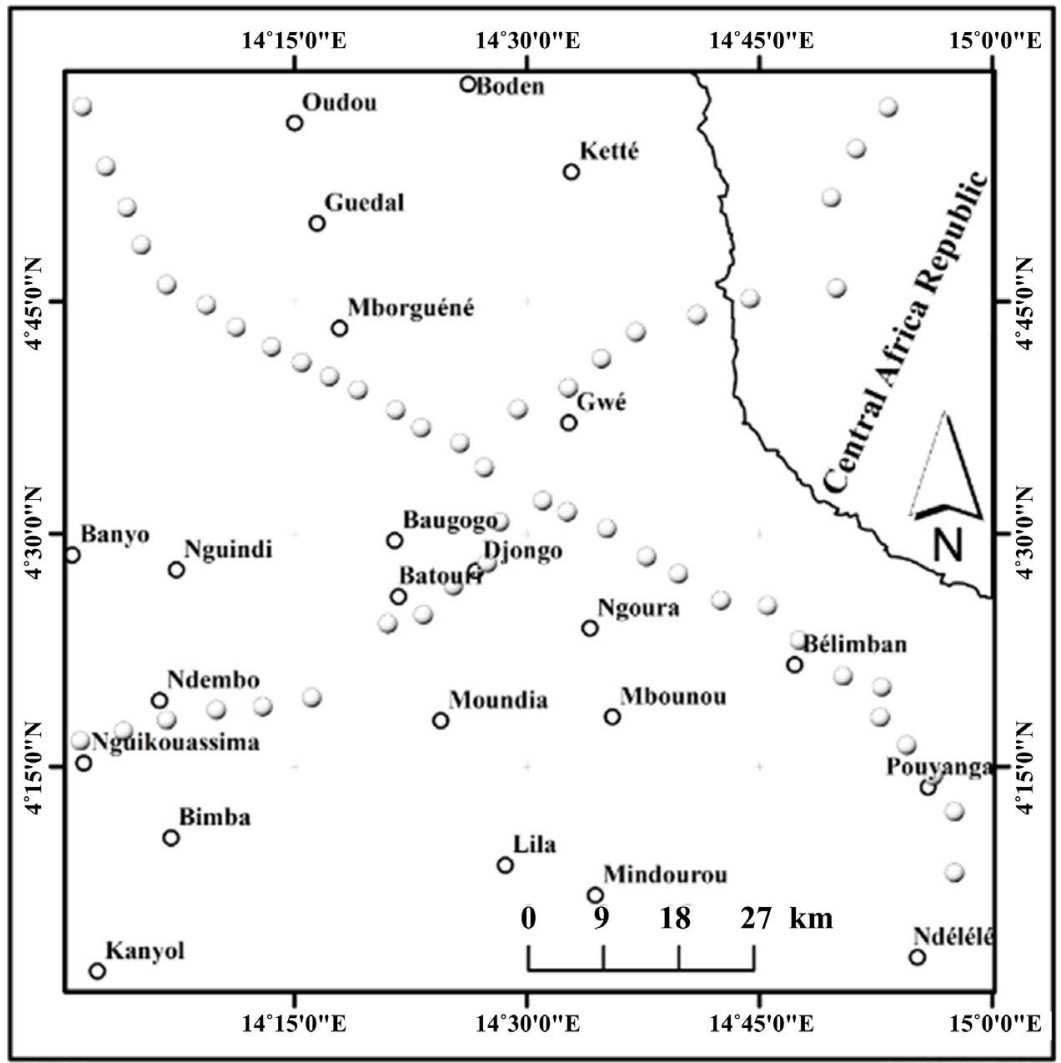

(a)

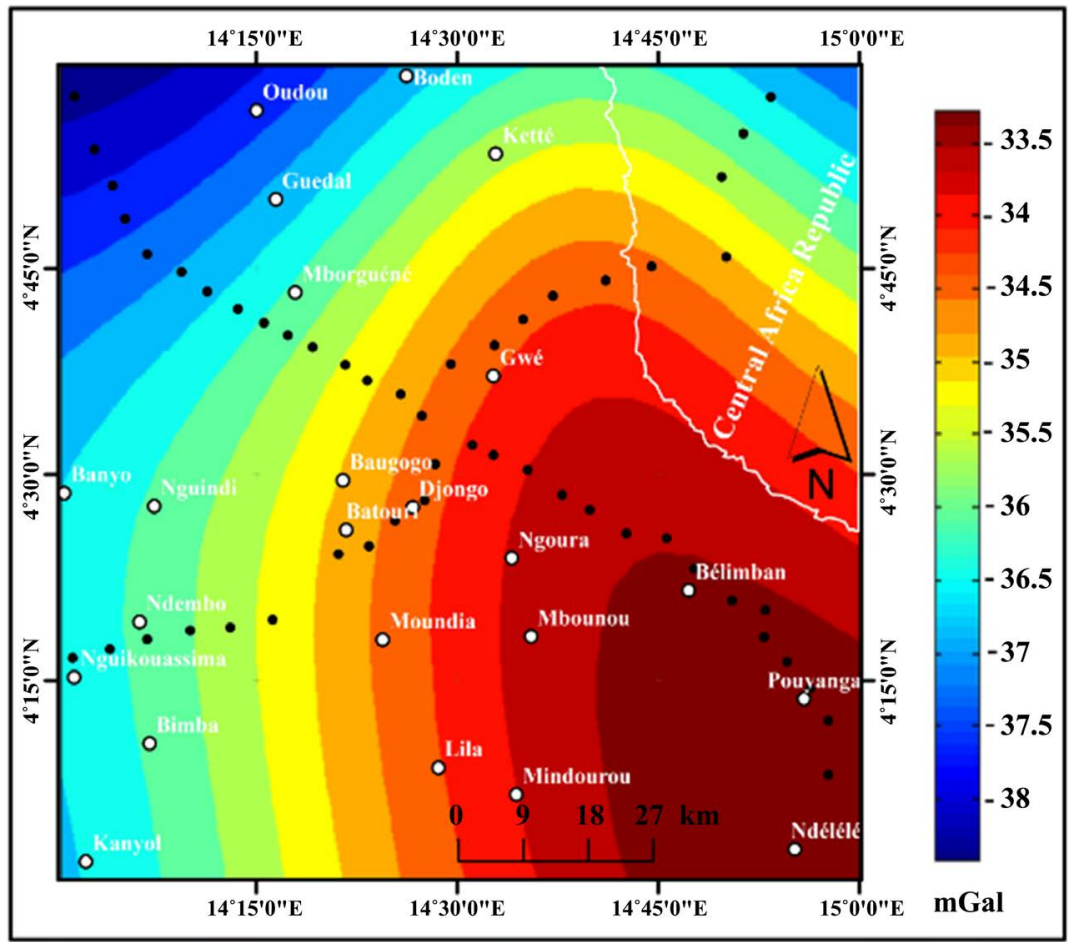

(b)

Figure 2. (a) Map of Bouguer data distribution after from Poudjom et al. (1996). (b) Bouguer gravity anomalies map of the study area. The map results from the interpolation of the map in (a). (Contour interval $=0.5 \mathrm{mGal}$ ). 
into regional and residual anomaly using a polynomial method. This filtering approach widely used by several authors [3] [8] has the advantage to solve the problem of non-uniqueness of the gravity or magnetic regional anomalies posed by other approaches as finite element and upward continuation methods; and it seems more objective, efficient and accurate [39]-[44].

The Bouguer anomaly values (690 values) obtained by interpolation of existing data (Figure 2(a)), were then gridded using the power inverse distance algorithm implemented in our Matlab separation code into a new Bouguer anomaly map of contour interval $0.50 \mathrm{mGal}$ (Figure 2(b)) that is very similar to those of [9] [12] [45]. As part of this work, two profiles were extracted on the residual map obtained after the data separation (Figure 3(a)) for spectral analysis and $2.5 \mathrm{D}$ modelling.

\section{Methodology}

The study applies the analytic polynomial regional-residual separation to the interpolated gravity anomalies grid. In addition, application of the 2D Fast Fourier Transform transforms gravity data from space to frequency so as to consider the depths average of the sources of anomalies. This approach is referred to as the qualitative and a preliminary quantitative interpretation of gravimetric anomalies [4] [46] [47].

\subsection{Analytic Polynomial Method: Regional-Residual Separation $(R-r S)$}

The method allows the estimation of regional anomaly by considering, on one hand that, it is regular with a slope that slightly varies; on the other hand, it is modelled using an analytical regional surface (2-D modelling).

Let $B(\mathrm{Pi})$, the value of Bouguer anomaly at the point $P(x, y)$; The objective is to calculate regional values $(\operatorname{Reg}(x, y))$ in $(\mathrm{Pi})$ and residual values $(\operatorname{Res}(x, y))$ in (Pi) by a suitably chosen polynomial $F(x, y)$ of $N$ order, which generates an analytical surface $\operatorname{Reg}(x, y)$ as close as possible to the experimental surface $B(x, y)$. The polynomial expression of the regional can be written as seen below [48]

$$
\begin{gathered}
F(x, y)=C_{1}+\sum_{J=1}^{N} \sum_{l=0}^{J} C_{m} A_{m}(x, y) \\
\text { or } F(x, y)=\sum_{m=1}^{M} C_{m} A_{m}(x, y)
\end{gathered}
$$

with $N$ : order of the polynomial

$$
\begin{gathered}
A_{m}(x, y)=x^{l} y^{j-l} \\
m=j(j+3) / 2-\ell+1
\end{gathered}
$$

$C_{m}$ : coefficient to be determined.

with $1 \leq m \leq M$ where $M=[(N+1)(N+2)] / 2$.

Defining $\varepsilon_{i}=B(x, y)-F(x, y)$, the difference between corresponding points of the experimental and analytical surfaces respectively, $N_{0}$ the number of points or Pi stations where observed Bouguer anomaly $B(\mathrm{Pi})$ is known. To adjust the 
surfaces, we must reduce to the minimum the square deviation:

$$
E=\sum_{i=1}^{N_{0}} \varepsilon_{i}^{2} \text { making } \frac{\partial E}{\partial C_{K}}=0 \quad(\text { avec } K=1,2, \cdots, M)
$$

This amounts to:

$$
\sum_{i=1}^{N_{0}} \varepsilon_{i} A_{k}(x, y)=\sum_{i=1}^{N_{0}}[B(x, y)-F(x, y)] A_{K}(x, y)=0
$$

Taking into account the above equations yields:

$$
\sum_{m=1}^{M} C_{m} \sum_{i=1}^{N_{0}} A_{K}(x, y) A_{m}(x, y)=\sum_{i=1}^{N_{0}} B(x, y) A_{K}(x, y)
$$

$C_{m}$ coefficients are obtained by solving the $M \times M$ system above with a MATLAB code following the polynomial degree. With $C_{m}$ coefficients, we deduce the regional analytical by the formula

$$
\operatorname{Reg}(x, y)=F(x, y) .
$$

The residual $\operatorname{Res}(\mathrm{x}, \mathrm{y})$ is calculated by the formula:

$$
\operatorname{Res}(x, y)=B(x, y)-\operatorname{Reg}(x, y) \text { with } x \text { and } y \text { in } \mathrm{km} \text {. }
$$

The residual and regional maps derived are useful in a qualitative study of the area.

\subsection{Inverse Square Distance Interpolation}

Generally, inverse distance-weighted gridding of gravity data enables to investigate the shape of the anomaly and then large geologic features are [49]. Thus, the inverse distance to a power gridding method is a weighted average either an exact or a smoothing interpolator. The study used the inverse square of the distance interpolation method whose formula is:

$$
B_{j}^{*}=\frac{\sum_{i=1}^{n} \frac{1}{h_{i j}^{\beta}} B_{i}}{\sum_{i=1}^{n} \frac{1}{h_{i j}^{\beta}}} \text { with } h_{i j}=\sqrt{d_{i j}^{2}+\delta^{2}} ;
$$

$h_{i j}$ represents the separation distance between the node $j$ on the grid and each of its neighbours $i$ brought back from the field.

$B_{j}^{*}$ is the interpolated value of the anomaly at node $j$ of the grid.

$\delta$ represents the smoothing parameter of anomalous iso-contours, $\beta$ is the power parameter.

\subsubsection{Constraints on the Choice of the Analytic Regional Polynomial of the Area}

The choice of the order of the polynomial representing the regional is not arbitrary; it depends on the nature of the residual anomaly to interpret. Generally, the more a regional is smoothed, the more it helps to eliminate only deep lines of the bark. If, again the regional analytical is a polynomial of high order, the lines closer to the surface will be the most accountable, which means that these lines will be of benefit shown in the residual. We must also consider assumptions 
suggested by the data set available that stick to the best geological and tectonic environment of the study. Data from the separation yielded regional and residual anomaly maps of different levels. The residual map of degree 3 (Figure 3) was chosen because it clearly identifies areas of positive anomalies, and negative gradients and also fits better with the geology of the region.

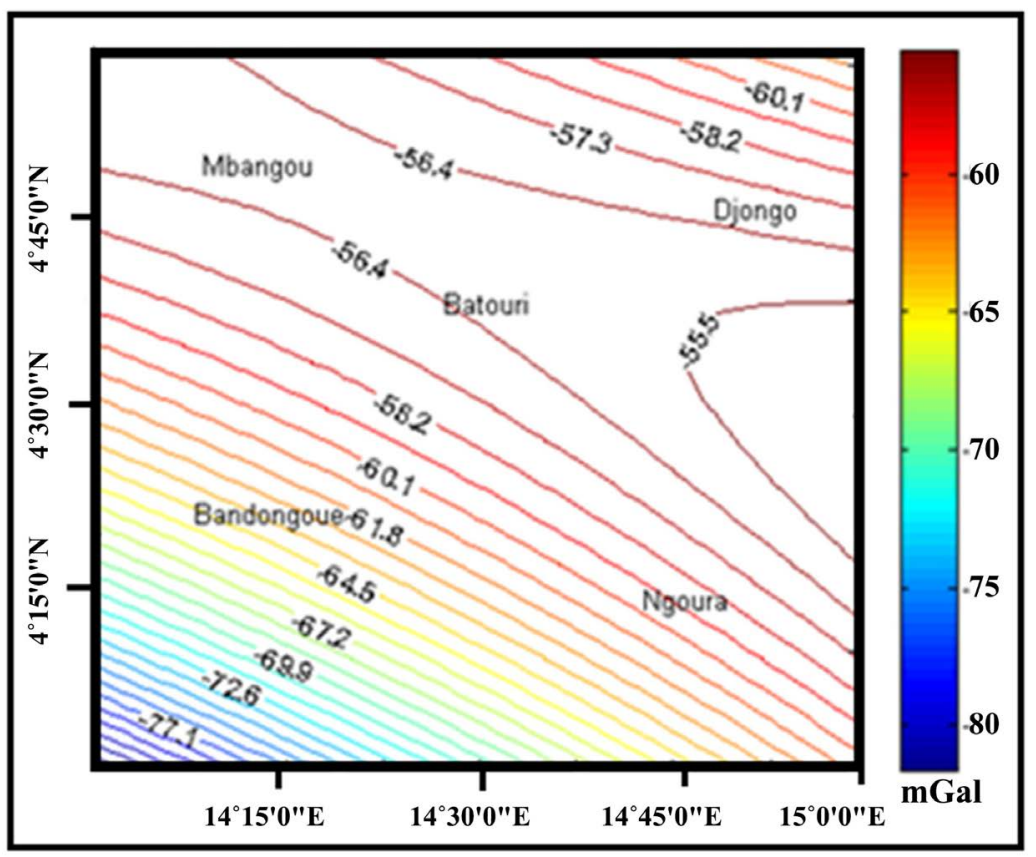

(a)

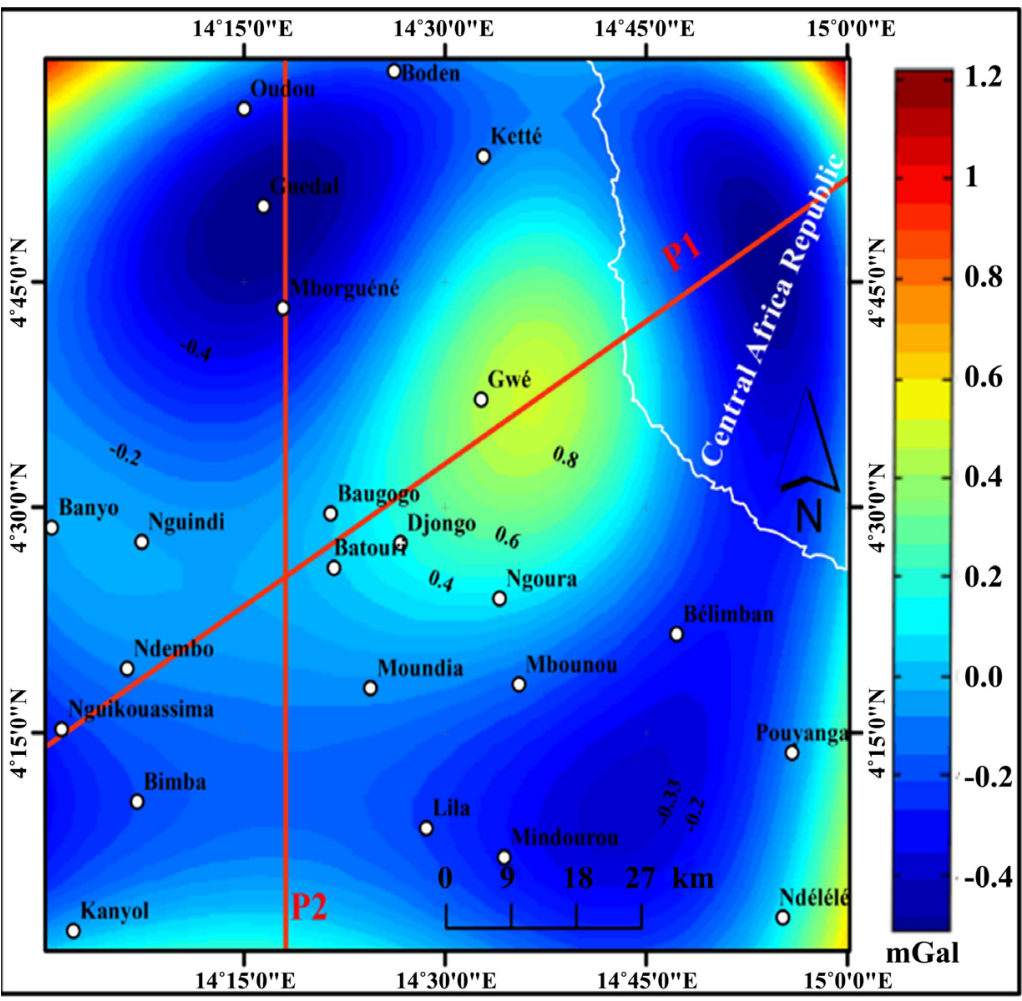

(b) 


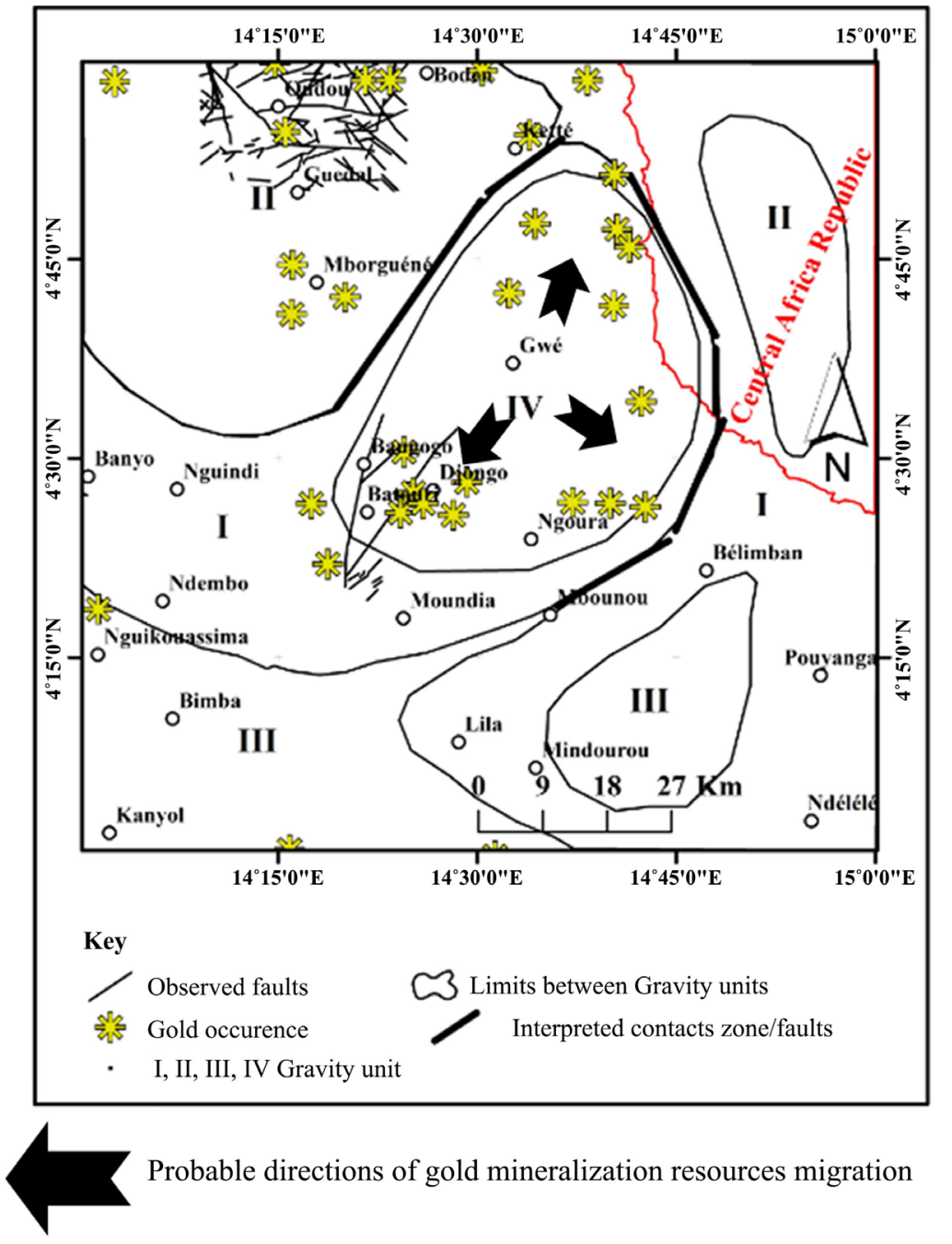

(c)

Figure 3. (a) Regional gravity anomalies map of the study area. (b) Residual gravity anomalies map of the study area with profiles (P1 and P2) for spectral analyses. The map results from the gridding data set used in (a) to conduct the residual separation based in the least square fitting of polynomial surfaces. (Contour interval $=0.1 \mathrm{mGal}$ ). (c) Gravity units map.

\subsubsection{Gravity Anomaly Maps and the Relations with Geological Structures}

The intensity of gravity measured at a point translated simultaneously, the effects of all the masses of the earth, the topography, and all the contrasts of densities inside the globe. The gravity anomaly maps express the density anomalies situated both in the superficial terrains and in the basement. The anomalies put in evidence on the regional anomaly map have large amplitude whose variations are greater than the one of the moho discontinuity [5] [8] [50]. Regional and residual maps are often used to interpret regional trends and localized structures of the subsurface geology. In a simple, qualitative interpretation, high-amplitude gravity maxima are interpreted as a major subsurface high and high-amplitude minima as deep basins [51]. 
The gravity anomalies have been grouped in fourth classes [5] [8] [51] [52] related to the shape of geological structures:

1) The closed circular isogales anomalies correspond to domes, grabens or basins, or to the mass of ore.

2) The closed ellipsoid shaped isogales anomalies with the long axis $\lambda$ and the short axis $\beta$ linked by $\lambda \geq 3 \beta$ correspond to synclines, the anticlines, lodes or to galleries.

3) The horizontal gradients correspond to the anomalies related to the change between two gravity levels. These gradients are provoked by folds or faults, down bending, fault steps affecting one or many formations;

4) The positive anomalies are associated with dense sedimentary rocks very dense intrusions in the crust, or to the uplift of substratum.

The negative anomalies are associated with the thickening of the sedimentary layers, slight intrusive rocks in the crust or to thickening of the crust.

\subsection{Spectral Analysis (SA)}

The application of spectral analysis $(S A)$ acknowledged many significant advances since its introduction in geophysics, as interpretation tool quantitative for potential field data by several authors [3] [46] [47] [53]-[60].

In this study, the spectral analysis estimates the average depths of the magnetic or gravimetric source bodies. SA does not require prior knowledge of the geometry, the density contrast or magnetic susceptibility of the causative bodies; it simply studies the power or energy spectrum as a function of wavelength or frequency. The power or energy spectrum of the anomaly will have dominant high frequency components when the anomaly is continued to the proximity of the source [61]. Thus, near-surface sources give flatter, as deeper sources give steeper power spectra [61]. The depth $(h)$ to an interface can be obtained by using the [55] equation. $S A$ operator is defined by the relation below:

$$
h=\Delta(\log E) / 4 \pi \Delta(n)
$$

where $E$ represents the energy spectrum; $\Delta(\log E)$ is the variation of logarithm of energy spectrum in the interval of frequency $\Delta(n)$. Depths obtained by spectral analysis are then used as constraints in the modeling so as to limit the non-uniqueness of the solutions for inverse problems to a unique solution. To propose a unique and acceptable geophysical model, information arising from spectral analysis or Euler deconvolution [12] [43] [44] [61] can constraint the depth of the observed anomalies in addition to available constraints to material properties from geological information or drilling data.

The data processing and interpretation was conducted through the following steps:

- The generation of a new dataset obtained by interpolating data from (Figure $2(a))$ in a $5 \mathrm{~km} \times 5 \mathrm{~km}$ grid. This led to a new Bouguer's anomaly map (Figure 2(b));

- The Regional-residual filtering based on the regional-residual analytical po- 
lynomial separation method [3] [4] [46] [59];

- The spectral analysis determines depth of the sources of observed anomaly(ies). In this step, curves are generated in Matlab based on the Fourier equation cited above. The depth value is deducted based on the linear regression approach;

The $2.5 \mathrm{D}$ modelling is done, by using spectral analysis results and geological facts as constrains. The density contrast of rocks is obtained by making the difference between the earth's crust $\left(d_{0}=2.67 \mathrm{~g} \cdot \mathrm{cm}^{-3}\right.$ and the various rock density $\left(d_{i}\right)$. The strike length is fixed to $100 \mathrm{~km}$, because of the extent of the study area. The maximum depth window for the modelling of residual anomaly is not exceeding $10 \mathrm{~km}$. For this modelling, the different rock types seemingly belong to the $\mathrm{PAB}[20]$ [21] [35] [62].

\section{Results and Discussions}

\subsection{Bouguer Gravity Anomalies}

In the area, the Bouguer anomaly features have a general ESE-WNW, NNESSW, N-S gravity gradient (Figure 2(b)). The map reflects lateral variations of the density in the basement and shows several anomalies with various values and shapes. It is characterized by gravity values ranging from $-40 \mathrm{mGal}$ to more than $-33 \mathrm{mGal}$. This is accordance with the fact that gravity data have been collected onshore and by the fact that it might indicate the transition zone of contact between the CC and the $\mathrm{PAB}$ or a fault zone around the $4^{\circ} \mathrm{N}$ parallel.

The map displays three main types of gravity anomalies over the area which are respectively high, intermediate and low values anomalies.

High gravity anomalies (values ranging from -35 to more than $-33 \mathrm{mGal}$ ) broadly correspond to a circular region covering $2 / 3$ of the study area, from east to west and south to north. This high gravity anomalous portion exhibits one oval peak centered at Ndélélé with a SE-NW major axis along in the Ndélélé-Gwé direction; and encompassing Ngoura, Mindourou and Bélimban, the peak may geologically correspond to either dense or basic deep intrusions within the main formations broadly characterized by the high intensity anomaly values; or probably to the uprising of some mantellic bodies. The anomaly field signal herein, most likely indicates the Neoproterozoic realm that occurs in the study area. The high gravity anomaly values domain is flanked to the north between Guedal-CAR by an intermediate anomaly portion (between $-37 \mathrm{mGal}$ to $-35 \mathrm{mGal}$ ) whose iso-lines present an approximately $\mathrm{E}-\mathrm{W}$ direction.

The intermediate Bouguer's anomaly portion forms a transition zone that separates the previous described domain from the low anomalies domain (Figure 2(b)). This suggests a probable gradational discontinuity steeping to north of the study area. It might also indicate the uplift of deeper mantellic bodies. This is probably deep faults affecting the basement (after the granitoids of central domain into NEFB) overlain by magmatic and metamorphic formations as shown by the geological map (Figure 1(b)). Low gravity anomalies (values lower than 
$-37 \mathrm{mGal}$ ) zone herein referred to as NW-NE portion of the map seemingly forms a combination of a NW and NE sub-basins. Anomalies can be related to existing lower density formations, probably basal complex granites (Figure 1(c)). The general disposition of anomalies on the Bouguer map of the study area shows a decrease in the anomaly field values from the west to east. This corresponds to a decrease in density from south to north. We therefore assume that formations to the south are denser than those to the north.

\section{1) Regional Gravity anomalies}

The regional gravity anomaly map (Figure 3(a)) shows regional gravity field values ranging from $-40 \mathrm{mGal}$ to $-32 \mathrm{mGal}$. The map was prepared by adjusting the data to a surface regional Bouguer $3^{\text {rd }}$ order polynomial. This map shows an overall set of negative isogales presenting a general NW-SE gradient. There is a group of isogales almost horizontal, identical and separated by a nearly circular area containing the iso-lines amplitude $-37 \mathrm{mGals}$. These two groups may correspond respectively to a very dense bedrock south of Gwé and a relatively dense in the region north of CAR separated by a flaw or discontinuity. The map exhibits a regional maximum assimilable to a thinning of the upper crust due to mantle materials uplift. The gravity gradient and the architecture of the contour lines on this map probably reflect the homogeneity of the basement of the region.

\section{2) Residual Gravity anomalies}

Residual anomalies are mainly variations of densities at the upper crust, including the variation of thicknesses and densities of the sedimentary rocks overlaying the basement; or either the density contrast induced by intrusive bodies.

The residual map (Figure $3(\mathrm{~b})$ ) is less similar to the Bouguer map. On this map of residual anomalies, two major gravity lows are observed. The first one, located to the east, is of composite nature and encompasses the towns of Bélimban and CAR to the northeast and southeast. This anomaly is separated from the second major anomaly located to the northwest (Guedal), by gravity high with an ellipsoid form centred on Gwé. The first anomaly is constituted by a large gravity low $(-0.57 \mathrm{mGal})$ at its eastern portion and with a mean NE-SW orientation. A second low of this first major anomaly is located to east of Bimba with a minimum of $-0.33 \mathrm{mGal}$. Gravity high puts these two anomalies in contact. To the north and south of gravity high, we have two gravity lows associable to trademarks of uprisings bedrock, or thickening of the crust, or the small intrusions in the metamorphic country rocks. The second global gravity low with a magnitude of $-0.45 \mathrm{mGal}$, is oriented NE-SW and encompasses Guedal. All these anomalies indicate that this transitional zone between Craton Congo (CC) and Pan African Belt (PAB) in the eastern Cameroon has a complex structure, made up of three sub-basins separated by structural highs (between Bélimban and CAR, a major and a minor one to Guedal). This suggests westward thinning of the sub-basins. The $0.7 \mathrm{mGal}$ contour coincides approximately with magmatic rocks.

The residual map does not keep the same form of contours as Bouguer field 
map (Figure 2(b)) but it matches more clearly the relative intensities of the levels of the gravimetric activity as well as the direction of isogales in different zones of the map. The localized anomalies (or related to near-surface sources) are strongly put forward with short wavelength anomaly amplitudes of ranging from -0.3 to $+1.2 \mathrm{mGal}$, bounded between latitudes $4^{\circ} \mathrm{N}$ to $5^{\circ} \mathrm{N}$ and longitudes $14^{\circ} \mathrm{E}$ to $15^{\circ} \mathrm{E}$. These residual field values may express the density variations of the surface gravimetric bodies directly relatable to the lateral variations of the geological units. Table 1 summarizes how the study area has been qualitatively delimited via residual gravimetric map, in gravity units (Figure 3(c)) presenting different gravimetric characteristics related to geologic formations (unit of the anomalies, the direction/shape of the profiles of the anomalies, the location of the contour patterns of anomalies, and the significance).

Mineral indices such as gold [10] are identified in the study area superimposed on gravity units map derived from residual anomaly (Figure 3(b)). For a better geological and structural correlation, the gravity units map (Figure 3(c)) has been supplemented with major well-known faults of Neoproterozïc Central Africa Fold Belt. Lode pre-gold mineralization of Batouri (Djongo) is located within little quartz veins associated with stockworks related respectively to NNW to WNW-trending faults aplite intrusions ( $40 \mathrm{~cm}$-wide dikes). These dikes are abundant in alkali-feldspar granites, but are rare in syeno-monzogranites and granodiorites [11]. The mineral architecture within the lode suggests that they were developed during an open-space tension. Syn-mineralized structures in the Batouri area are manifested by the about $13 \mathrm{~km}$-long, NE-trending shear zone, which cuts mainly granodiorites and syeno-monzo-granites. The width of the shear zone (including minor anastomosing shears) ranges from $100 \mathrm{~m}$ to 1 $\mathrm{km}$. This zone hosts most of the gold-bearing quartz veins in the area. Gold-bearing quartz veins trend NNE-SSW, NE-SW, and ENE-WSW (Figure 3(c)). Postmineralization structures are represented by multidirectional normal faults and joints. ENE-WSW Barren quartz veins commonly associated with pegmatite dikes (e.g. at Baugogo), with a few millimetres to $14 \mathrm{~m}$ thickness, are also widespread in the Batouri area. These barren quartz veins are composed of milky or

Table 1. Main gravity units of the study area from gravity signatures of the residual map related to geological features (Figure $3(\mathrm{c})$ ).

\begin{tabular}{|c|c|c|c|}
\hline Units & Direction/shape & Location & Significance \\
\hline Unit I & $\begin{array}{l}\text { NW-SE to N-S } \\
\text { (linear) }\end{array}$ & Banyo-Bélimban & $\begin{array}{c}\text { Contact Precambrian rock } \\
\text { of basement metamorphic series }\end{array}$ \\
\hline Unit II & N-S (ellipsoïd) & Guedal-CAR & $\begin{array}{l}\text { Granodiorites, Calc-alkaline and Alkaline } \\
\text { granites (Precambrian basement rock) } \\
\text { Panafricain Post-tectonic and late } \\
\text { syn-tectonic granites (Granitoïds) }\end{array}$ \\
\hline Unit III & W-E & SE-Bimba & $\begin{array}{l}\text { Anastexites and embrechites } \\
\text { gneisses (metamorphic series) }\end{array}$ \\
\hline Unit IV & $\begin{array}{l}\text { NE-SW to NW-SE } \\
\text { (Circular) }\end{array}$ & $\begin{array}{l}\text { Batouri-Gwé and } \\
\text { Ngoura }\end{array}$ & $\begin{array}{l}\text { Intrusion of anastexites } \\
\text { (metamorphic series) }\end{array}$ \\
\hline
\end{tabular}


smoky quartz, characterized by drusy textures with abundant vugs [11] [12] Gold mineralization within quartz veins is therefore the result of intense tectonics enabling fluid circulation in faults. Several gold deposits are identified in Batouri shear zone and the surrounding localities such as Gwé and Ngoura (Unit IV). However, Guedal and Bélimban are located in a negative residual anomaly and separated by a positive anomaly of Gwé. Likewise, Banyo (Unit I) could be consider as the NW-ending of Batouri-Gwé and Ngoura gravity unit which hosts gold deposits. These gravity units specially describe a probable directions of gold mineralization migration. Clearly, the regional-residual polynomial separation technique efficiently revealed a specific anomaly (positive anomaly of Gwé) linkable to primary gold mineralizations.

\subsection{Spectral Analysis of the Residual Map}

The spectral analysis (Figure 4) carried out on the residual map along the profiles P1 and P2 (Figure 3(b)), enabled to significantly estimate the depth of the bodies in the higher crust, source of the observed anomalies (Table 2). The first depth Hres1 of about $2.54 \mathrm{~km}$ for P1 and $1.66 \mathrm{~km}$ for P2, represents the higher depth to the bottom of body responsible for the observed anomaly, while the Hres2 depth of $0.50 \mathrm{~km}$ on $\mathrm{P} 1$ and $0.30 \mathrm{~km}$ on $\mathrm{P} 2$, respectively, translated the upper limit of the causative anomaly sources. In short, these heights would globally translate depth range of the bodies suspected in these zones. Those depths obtained from the spectral analysis were used as constraints of the $2.5 \mathrm{D}$ modelling.

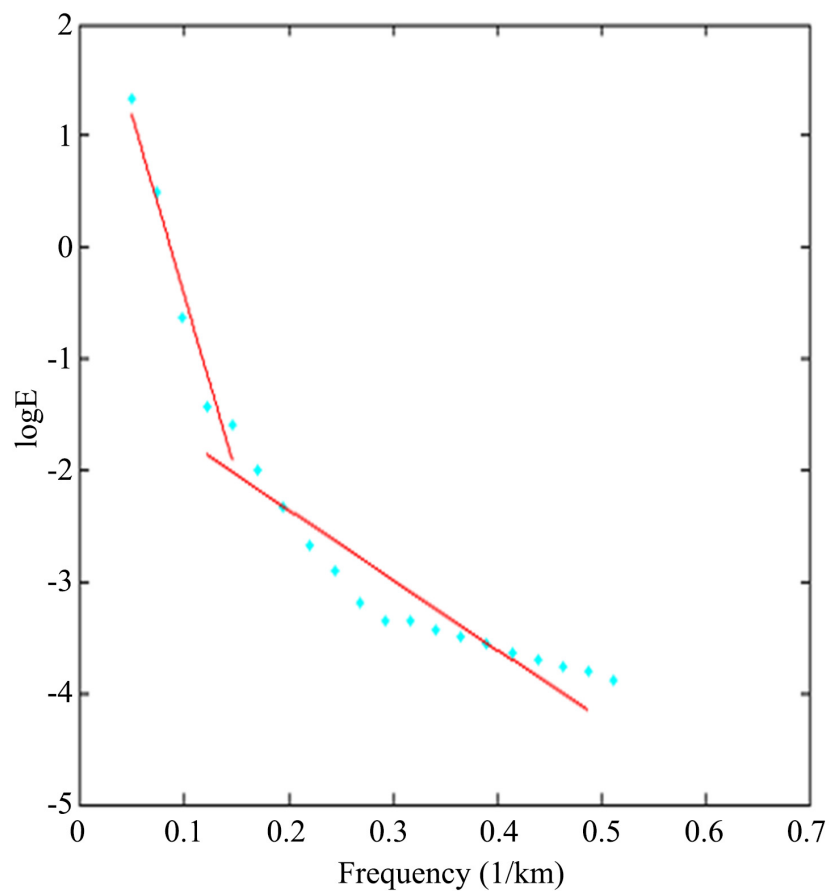

(a)

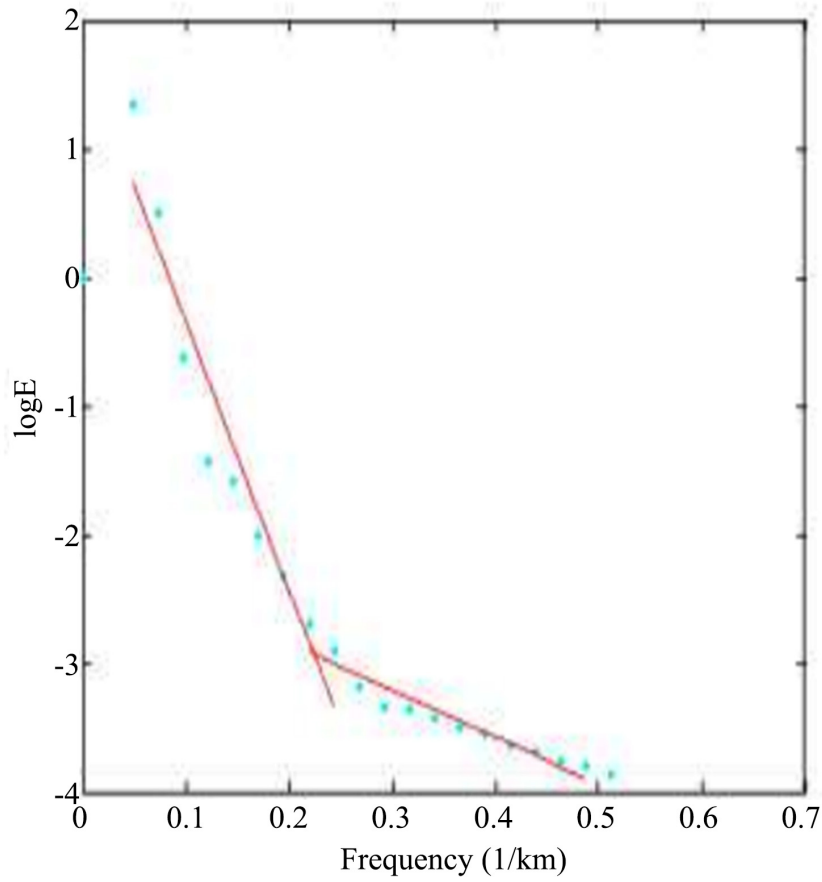

(b)

Figure 4. Power spectrum curves of the residual field profiles (P1 and P2). (a) P1; (b) P2. 
Table 2. Depth obtained from spectral analysis on gravity residual map in kilometres $(\mathrm{km})$.

\begin{tabular}{cccc}
\hline Profile & Direction & Hres1 & Hres2 \\
\hline Batouri-Gwé (P1) & N-S & $1.66 \pm 0.22$ & $0.30 \pm 0.04$ \\
Guedal-Mborguéné (P2) & SW-NE & $2.54 \pm 0.18$ & $0.50 \pm 0.30$ \\
\hline
\end{tabular}

Table 3. Modelled geometric parameters of gravity bodies of P2 profile. Depths are in kilometres $(\mathrm{km})$.

\begin{tabular}{cccccc}
\hline \multicolumn{7}{c}{ Profile P2 } \\
\hline $\begin{array}{c}\text { Density contrast } \\
(\text { CGS unit })\end{array}$ & $\begin{array}{c}\text { Depth } \\
(\mathrm{km})\end{array}$ & Width $(\mathrm{km})$ & $\begin{array}{c}\text { Transversal } \\
\text { extension }(\mathrm{km})\end{array}$ & $\begin{array}{c}\text { Vertical } \\
\text { extension }(\mathrm{km})\end{array}$ \\
\hline Body 1 & -0.07 & 0.3 & 5.2 & 50 & 3 \\
Body 2 & -0.037 & 0.4 & 6.4 & 10 & 3.2 \\
Body 3 & -0.026 & 0.3 & 6.7 & 10 & 3.2 \\
Body 4 & 0.084 & 0.7 & 8.4 & 10 & 2.9 \\
\hline
\end{tabular}

Table 4. Geometric parameters of gravity bodies, model of P1 profile. Depths are in kilometres $(\mathrm{km})$.

\begin{tabular}{cccccc}
\hline \multicolumn{7}{c}{ Profile P1 } \\
\hline $\begin{array}{c}\text { Density contrast } \\
\text { (CGS unit) }\end{array}$ & $\begin{array}{c}\text { Depth } \\
(\mathrm{km})\end{array}$ & $\begin{array}{c}\text { Width } \\
(\mathrm{km})\end{array}$ & $\begin{array}{c}\text { Transversal } \\
\text { extension }(\mathrm{km})\end{array}$ & $\begin{array}{c}\text { Vertical } \\
\text { extension }(\mathrm{km})\end{array}$ \\
\hline Body 1 & 0.08 & 0.4 & 6.9 & 20 & 2.9 \\
Body 2 & -0.07 & 0.4 & 7.2 & 50 & 2.6 \\
Body 3 & 0.03 & 0.3 & 6.1 & 50 & 2.5 \\
\hline
\end{tabular}

\subsection{5D Modelling}

The 2.5D modelling of surface formations from study area was conducted with the Grav2DC $2.10^{\circledR}$ [63]. Through this software, modelling involves the calculation of the density contrast, depth, thickness; and estimation of the geometry of the anomalous buried body. The hypothetical model for each profile is the one ensuring the best fit (or superposition) between the experimental and the calculated curves.

For this quantitative study, we plotted two gravity profiles P1 and P2 of respective directions N-S and NE-SW (Figure 3(b)) on the residual map. These profiles were selected from areas of interest where the anomalies are much tighter and ellipsoidal. The reconciliation of these profiles with the geological map shows that P1 traverses from south to north, syenites, migmatites, anatexic granites, gneisses and schists; while $\mathrm{P} 2$ traverses granites and post and syn-tectonic gneisses. Table 3 and Table 4 above summarise the modelled bodies hereafter described for profile 2 and profile 1, respectively.

For profile P2, we obtained a model (Figure 5) defined by a $4^{\text {th }}$ order polynomial curve with two relative maxima and a minimum, characterising a fault. This curve allows -5.72 mgals for minimum and maximum 3.81 mgals north; a 


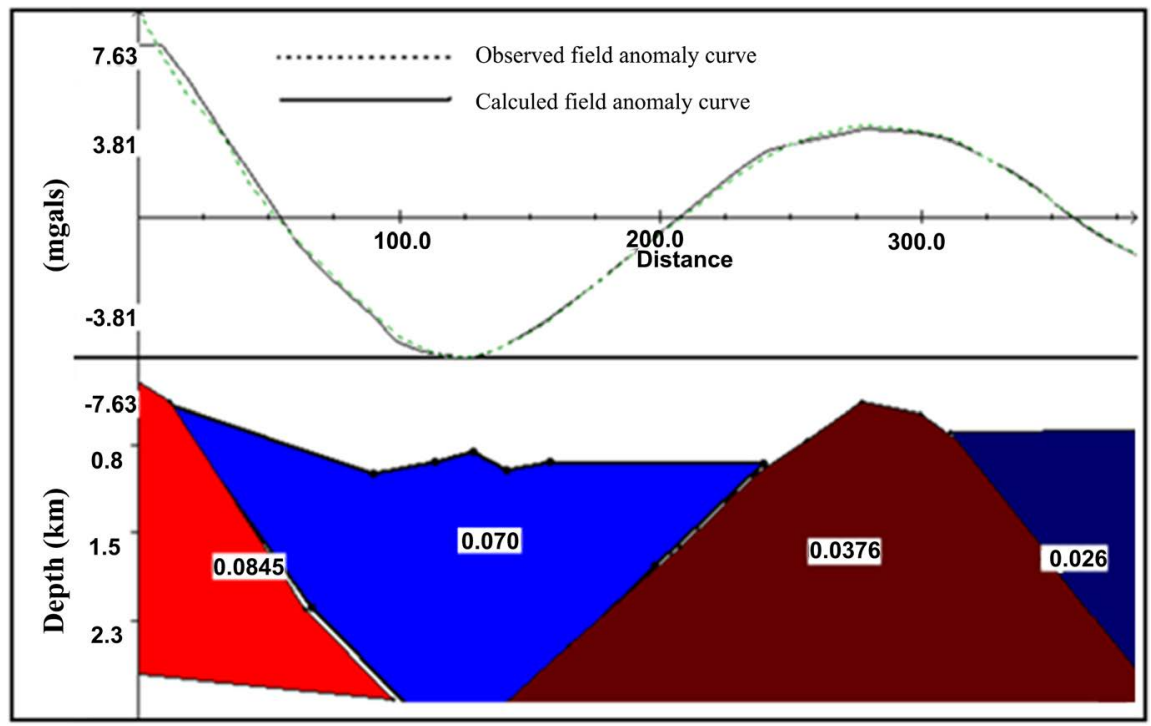

Figure 5. 2.5D model of profile P2.

relative maximum variable 9.54 mgals south. The terrain model which follows from the gravity profile is a four lithologic units model.

\section{Body 1}

Its $2.75 \mathrm{~g} / \mathrm{cm}^{3}$ density is characteristic of gneiss outcrops in southwestern Baugogo. Further, the same area flushes with ancient syntectonic granites formations in the south.

\section{Body 2}

With $2.6 \mathrm{~g} / \mathrm{cm}^{3}$ density, it can be associated to late syntectonic granite met in the heart of Baugogo. The E-trending fault in the $\mathrm{W}$ region, as prortrayed in the gradient observed above $3^{\circ} \mathrm{N}$ parallel, can also correspond to a discontinuity or lithological contact between the gneiss and late granite.

\section{Body 3}

It has $2.7 \mathrm{~g} / \mathrm{cm}^{3}$ density and it is associated with anatexic granites met mostly in the heart of Batouri. The overlap between the late syntectonic granites of Baugogo anatexites and granites south of Batouri would be a flaw. Additionally, an anomaly gradient observed around SN parallel $4^{\circ} \mathrm{N}$ may clearly highlight a fault between Southern and Northern Batouri-Baugogo.

\section{Body 4}

Whit $2.65 \mathrm{~g} / \mathrm{cm}^{3}$ density, it can be associated with shale encountered at northern Gwé. The discontinuity observed in this model is probably the lithological contact between the granites and Batouri schists observed in the Moundia area, as shown by the gradient observed around the parallels $4^{\circ} 50^{\prime} \mathrm{N}$. The flaw characterized by the gradient observed between E-W direction and Baugogo-Batouri has a depth of nearly $2800 \mathrm{~m}$ and the upper roof of the fault would be deeper than $800 \mathrm{~m}$.

In profile $\mathrm{P} 1$, we obtained a model which is defined by a $4^{\text {th }}$ order polynomial, more spread that the curve displayed in profile P2. This curve allows 


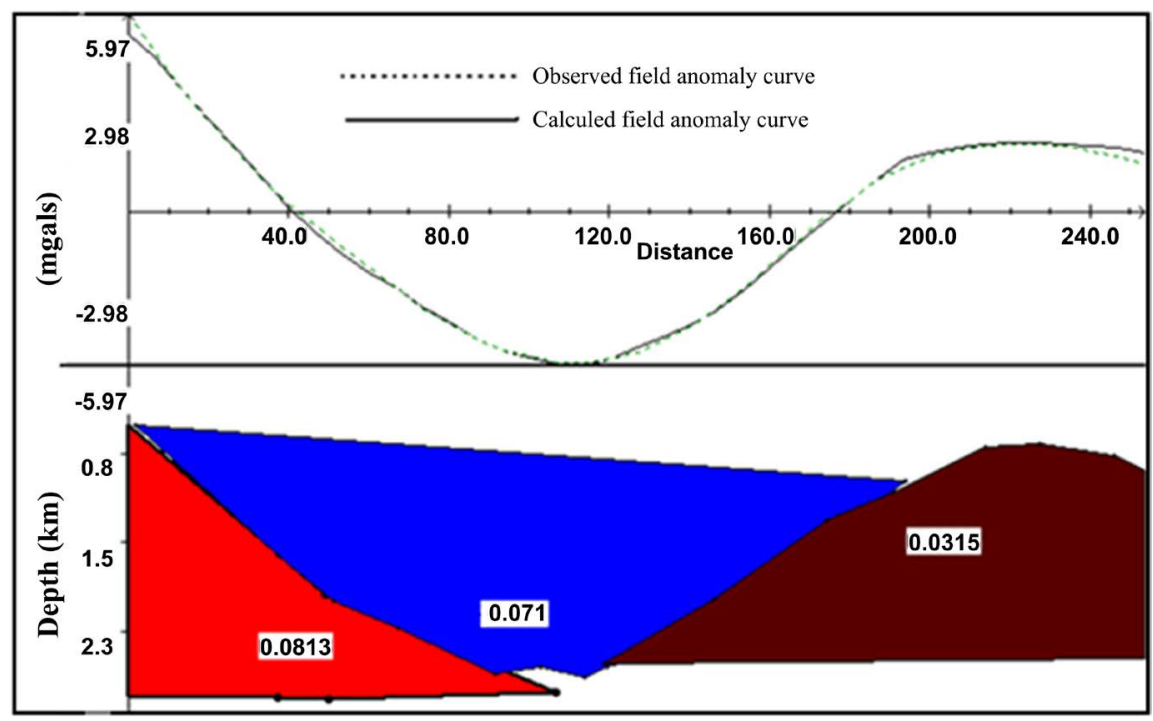

Figure 6. 2.5D model of profile $\mathrm{P} 1$.

for minimum-4.47 magls and maximum 7.42 mgals on the south. The terrain modelled from the profile 1 exhibits three lithologic units (Figure 6).

\section{Body 1}

Density $2.75 \mathrm{~g} / \mathrm{cm}^{3}$, it is characteristic formations of gneiss with an average density of $2.8 \mathrm{~g} / \mathrm{cm}^{3}$. This seems to be gneiss unconformably laying on late syntectonic granites of the area. Note here that the linearly increasing gravity gradient in the $\mathrm{E}-\mathrm{W}$ direction is observed above the $3^{\circ} \mathrm{N}$ parallel. This model may correspond to a discontinuity or contact between the gneisses and granites.

\section{Body 2}

This body has $2.6 \mathrm{~g} / \mathrm{cm}^{3}$ density and it can be associated to syn to late-tectonic granites met Bandongoue.

\section{Body 3}

With a $2.7 \mathrm{~g} / \mathrm{cm}^{3}$ density, it can be associated to old syntectonic granites which outcrop mainly in Mbangou above the parallel of $4^{\circ} \mathrm{N}$. The discontinuity observed in this model is probably a contact between the granites of different ages. Note also that the N-S linear gradient identified around $4^{\circ} \mathrm{N}$ parallel, precisely between north and south Guedal-Mbaorguéné identifies this fault E-W direction. Observed between the fault and Batouri-Gwé have a $2300 \mathrm{~m}$ depth.

\section{Conclusion}

In this study, we used the method of interpolation by the inverse square of the distance, a method that requires the introduction of a quantity called strictly positive smoothing parameter (smoothing factor), depending on data. As part of this study, it is $\delta=45$. Spectral analysis of data along the profiles P1 and P2 we were localized at $2.54 \mathrm{~km}$ and $1.66 \mathrm{~km}$ deep above the roof of the body and at $0.50 \mathrm{~km}$, and $0.30 \mathrm{~km}$ respectively, the lower limit of structures responsible for major anomalies. The maximum depth of the sources detected in the P1 profile realized on the map of Bouguer is $8 \mathrm{~km}$. Processing and modelling of gravity da- 
ta from Batouri permitted us to get third order residual maps on which two profiles have been drawn to highlight subsurface structure models. These models are characterized by the thickness, density contrast, depth to the top, the geologic shape, the width and major tectonic unevennesses. Gravity profiles studied were interpreted into three or four terrain models. Structural analysis of models shows that the basement presents many intrusions responsible of the anomalies observed. High wavelength anomalies in the northeast Batouri are mainly due to schist or light granite intrusions. Light anomalies in the south of Baugogo can be related to a collapse of a terrain or the basement. The over thrust line between late syntectonic granites in the north Baugogo and anatexic granites in the south of Batouri, may be an E-W fault as suggested by S-N gravity gradient. The throw of this fault is $2800 \mathrm{~m}$. Spectral analysis of data along profiles has permit to locate anomalies at $8 \mathrm{~km}, 2.5 \mathrm{~km}$ and $1.7 \mathrm{~km}$ depth.

\section{Acknowledgements}

Comments and suggestions by two anonymous reviewers greatly helped to improve the paper.

\section{Conflicts of Interest}

The authors declare no conflicts of interest regarding the publication of this paper.

\section{References}

[1] Blum, B.L.M., Pires, B.C.A. and De moraes, V.A.R. (2000) Gravity Inversion on Granite-Greenstone Belt Areas/Crixäs. Guarinos and Pilar de Goiäs, Brazil. Revista Brasileira de Geociências, 30, 547-550. https://doi.org/10.25249/0375-7536.2000303547550

[2] Njandjock, N.P., Manguelle, D.E., Ndougsa, M.T. and Tabod, T.C. (2006) Spectral Analysis and Gravity Modelling in the Yagoua, Cameroon, Sedimentary Basin. Geofísica Internacional, 45, 209-215.

[3] Ndougsa Mbarga, T., Manguelle-Dicoum, E. and Sharma, K.K. (2007) Integration of the Finite Element Approach (FEA) in Gravity Processing for Solid Minerals Potentialities over the Congo Craton Belt in Cameroon and South West Central African Republic. European Geosciences Union, Geophysical Research Expanded Abstracts, Vol. 9, Article ID: 00015.

[4] Fraser, G. (1957) A Problem in the Analysis of Geophysical Data. Geophysics, 22, 309-344. https://doi.org/10.1190/1.1438363

[5] Thurston, J.B. and Brows, R.J. (1992) The Filtering Characteristics of Least-Squares Polynomial Approximation for Regional/Residual Separation. Canadian Journal of Exploration Geophysics, 28, 71-80.

[6] Dobrin, M.B. and Savit, C.H. (1988) Introduction to Geophysical Prospecting. Mc Graw-Hill, Toronto, 600-607.

[7] Parasnis, D.S. (1975) Principles of Applied Geophysics. 5th Edition, Chapman and Hall, London, 429 p.

[8] Poudjom, D.Y.H., Boukeke, D.B., Nnange, J.M., Bekoa, A., Albouy, Y. and Fairhead, 
J.D. (1996) Levés gravimétriques de reconnaissance du Cameroun. Office de la Recherche Scientifique et Technique Outre-Mer, Paris, 28 p.

[9] Suh, C.E. (2008) Sulphide Microchemistry and Hydrothermal fluid Evolution in Quartz Veins, Batouri Gold District (Southeast Cameroon). Journal of the Cameroon Academy of Sciences, 8, 19-30.

[10] Asaah, A.V., Zoheir, B., Lehmann, B., Frei, D., Burgess, R. and Suh, C.E. (2014) Geochemistry and Geochronology of the $\sim 620$ Ma Gold-Associated Batouri Granitoids, Cameroon. International Geology Review, 57, 1485-1509. https://doi.org/10.1080/00206814.2014.951003

[11] Vishiti, A., Suh, C.E., Lehmann, B., Egbe, J.A. and Shemang, E.M. (2015) Gold Grade Variation and Particle Microchemistry in Exploration Pits of the Batouri Gold District, SE Cameroon. Journal of African Earth Sciences, 111, 1-13. https://doi.org/10.1016/j.jafrearsci.2015.07.010

[12] Claude, N.P., Clotilde, O.A., Marcelin, B.B., Antoine, W.K., Igor, O.A. and Théophile, N.M. (2016) Evidence by Multi-Scale Analysis of Lineaments Derived from Gravity Anomalies in the Batouri Area (Eastern-Cameroon). International Journal of Science and Research, 5, 866-874. https://doi.org/10.21275/v5i2.NOV161206

[13] Gazel, J. and Gerard, G. (1954) Carte géologique de reconnaissance du Cameroun au 1/500000, feuille de Batouri-Est avec notice explicative. Mémoire Direction des Mines et de la Géologie, Yaoundé, 43 p.

[14] Takodjou Wambo, J.D., Ganno, S., Afahnwie, N.A., Nomo, N.E., Mvondo, O. J. and Nzenti, J.P. (2016) Use of Landsat 7 ETM+ Data for the Geological Structure Interpretation: Case Study of the Ngoura-Colomines Area, Eastern Cameroon. Journal of Geosciences and Geomatics, 4, 61-72.

[15] Castaing, C., Triboulet, C., Feybesse, J.L. and Chèvremont, P. (1994) Tectonometamorphic Evolution of Ghana, Togo, Benin in the Light of the Pan-African/Braziliano Orogeny. Tectonophysics, 218, 323-342. https://doi.org/10.1016/0040-1951(93)90322-B

[16] Toteu, S.F., Penaye, J. and Poudjom, D.Y. (2004) Geodynamic Evolution of the Pan-African Belt in Central Africa with Special Reference to Cameroon. Canadian Journal of Earth Sciences, 41, 73-85. https://doi.org/10.1139/e03-079

[17] Van Schmus, W.R., Oliveira, E.P., Da Silva Filho, A.F., Toteu, S.F., Penaye, J. and Guimarães, I.P. (2008) The Central African Fold Belt Proterozoic Links between the Borborema Province, NE Brazil, and the Central African Fold Belt. Geological Society, London, Special Publications, 294, 69-99. https://doi.org/10.1144/SP294.5

[18] Cornacchia, M. and Dars, R. (1983) Un trait structural majeur du continent Africain: Les linéaments centrafricains du Cameroun au Golfe d'Aden. Bulletin de la Société Géologique de France, 25, 101-109. https://doi.org/10.2113/gssgfbull.S7-XXV.1.101

[19] Vignes-Adler, M., Le Page, A. and Adler, P.M. (1991) Fractal Analysis of Fracturing in Two African Regions from Satellite Imagery to Ground Scale. Tectonophysics, 196, 69-86. https://doi.org/10.1016/0040-1951(91)90290-9

[20] Nzenti, J.P. (1992) Prograde and Retrograde Garnet Zoning at High Pressure and Temperature in Metapelitic and Grenatite Rocks from Yaoundé (Cameroon Pan-African North-Equatorial Fold Belt). Journal of African Earth Sciences (and the Middle East), 15, 73-79. https://doi.org/10.1016/0899-5362(92)90008-Z

[21] Nzenti, J.P., Barbey, P. and Tchoua, F.M. (1999) Evolution crustale au Cameroun: Eléments pour un modèle géodynamique de l'orogenèse néoprotérozoïque. In: Vicat, J.P. and Bilong, P., Eds., Ingéologie de Penvironnement au Cameroun, Collec- 
tion Géocam 2, Presse de l’Université de Yaoundé I, Yaoundé, 397-407.

[22] Bessoles, B. and Lasserre, M. (1977) Le complexe de base du Cameroun. Bulletin de la Société Géologique de France, 19, 1085-1092.

https://doi.org/10.2113/gssgfbull.S7-XIX.5.1085

[23] Bessoles, B. and Trompette, M. (1980) Géologie de l'Afrique: La chaîne Panafricaine, "Zone mobile d'Afrique centrale (partie sud) et Zone mobile soudanaise". Mémoires du Bureau de recherches géologiques et minières, No. 92, Editions B.R.G.M., Orléans, 19-80.

[24] Penaye, J., Toteu, S.F., Van Schmus, W.R., Tchakounté, J., Ganwa, A., Minyem, D. and Nsifa, E.N. (2004) The 2.1-Ga West Central African Belt in Cameroon: extension and evolution. Journal of African Earth Science, 39, 159-164. https://doi.org/10.1016/j.jafrearsci.2004.07.053

[25] Shang, C.K., Satir, W.S.M. Chen, F. and Mvondo-Ondoua, J. (2004) Zircon Pb-Pb and U-Pb Systematics of TTG Rocks in the Congo Craton: Constraints on Crust Formation, Magmatism, and Pan-African Lead Loss. Bulletin of Geosciences, 79, 205-219.

[26] Ganwa, A.A., Frisch, W., Siebel, W., Ekodeck, E.G., Shang, C.K. and Ngako, V. (2008) Archean Inheritances in the Pyroxene-Amphibole-Bearing Gneiss of the Méiganga Area (Central North Cameroon): Geochemical and ${ }^{207} \mathrm{~Pb} /{ }^{206} \mathrm{~Pb}$ Age Imprints. Comptes Rendus Geoscience, 340, 211-222.

https://doi.org/10.1016/j.crte.2007.12.009

[27] Penaye, J., Toteu, S.F., Van Schmus, W.R. and Nzenti, J.P. (1993) Up-Pb and Sm-Nd Preliminary Geochronologic Data on the Yaounde Series, Cameroon: Reinterpretation of the Granulitic Rocks as the Suture of a Collision in the Central African "Belt". Comptes Rendus de l Académie des Sciences, Paris, 317, 789-794.

[28] Nzenti, J.P., Barbey, P., Bertrand, J.M. and Macaudière, J. (1994) La Chaîne panafricaine au Cameroun: Cherchons suture et modèle. 15ème Réunion des Sciences de la Terre, Nancy, France, Société Géologique de France, 99.

[29] Tanko Njiosseu, E.L., Nzenti, J.P., Njanko, T., Kapajika, B. and Nedelec, A. (2005) New U-Pb zircon âges from Tonga (Cameroon): Coexisting Eburnean-Transamazonian $(2.1 \mathrm{Ga})$ and Pan-African (0.6 Ga) Imprints. Comptes Rendus Geoscience, 337, 551-562. https://doi.org/10.1016/j.crte.2005.02.005

[30] Toteu, S.F., Van Schmus, W.R., Penaye, J. and Michard, A. (2001) New U-Pb and Sm-Nd Data from North-Central Cameroon and Its Bearing on Pre-Pan-African History of Central Africa. Precambrian Research, 108, 45-73. https://doi.org/10.1016/S0301-9268(00)00149-2

[31] Djouka-Fonkwe, M.L., Schulz, B., Schüssler, U., Tchouankoué, J.P. and Nzolang, C. (2008) Geochemistry of the Bafoussam Pan-African I- and S-Type Granitoids in Western Cameroon. Journal of African Earth Science, 50, 148-167. https://doi.org/10.1016/j.jafrearsci.2007.09.015

[32] Nzenti, J.P., Kapajika, B., Wörner, G. and Lubala, R.T. (2006) Synkinematic Emplacement of Granitoids in a Pan-African Shear Zone in Central Cameroon. Journal of African Earth Science, 45, 74-86. https://doi.org/10.1016/j.jafrearsci.2006.01.005

[33] Nzenti, J.P., Abaga, B., Suh, C.E. and Nzolang, C. (2011) Petrogenesis of Peraluminous Magmas from the Akum-Bamenda Massif, Pan-African Fold Belt, Cameroon. International Geology Review, 53, 1121-1149.

https://doi.org/10.1080/00206810903442402

[34] Ngako, V., Affaton, P., Nnange, J.M. and Njanko, Th. (2003) Pan-African Tectonic Evolution in the Central and the Southern Cameroon: Transpression and Transten- 
sion during Sinistral Shear Movements. Journal of African Earth Sciences, 36, 207-214. https://doi.org/10.1016/S0899-5362(03)00023-X

[35] Mvondo, H., Den-Brok, S.W.J. and Mvondo-Ondoa, J. (2003) Evidence for Symmetric Extension and Exhumation of the Yaoundé Nappe (Pan-African Fold Belt, Cameroon). Journal of African Earth Sciences, 35, 215-231. https://doi.org/10.1016/S0899-5362(03)00017-4

[36] Eno Belinga, S.M. (1984) Géologie du Cameroun. Librairie Universitaire de Yaoundé, République Unie du Cameroun, Yaoundé, 307 p.

[37] Lasserre, M. and Soba, D. (1976) Âge libérien des granitoïdes et des gneiss à pyroxène du Cameroun méridional. Bulletin du Bureau de Recherches Géologiques et Minières, 2, 17-32.

[38] Milesi, J.P., Toteu, S.F., Deschamps, Y., Feybesse, J.L., Lerouge, C., Cocherie, A., Tchameni, R., Moloto-A-Kenguemba, G., Kampunzu, H.A.B., Nicol, N., Duguey, E., Leistel, J.M., Saint-Martin, M., Ralay, F., Heinry, C., Doumnang Mbaigane, J.C., Chêne, F., Monthel, J., Boutin, P. and Rolin, P. (2004) Geology and Major Ore Deposits of Central Africa. Bureau de Recherches Géologiques et Minières, Orleans.

[39] Mallick, K. and Sharma, K.K. (1997) Computation of Regional Gravity Anomaly-A Novel Approach. Proceedings of the Indian Academy of Sciences. Earth and Planetary Sciences, 106, 55-59.

[40] Mallick, K. and Sharma, K.K. (1999) A Finite Element Method for Computation of the Regional Gravity Anomaly. Geophysics, 64, 461-469. https://doi.org/10.1190/1.1444551

[41] Kaftan, I., Mujgan, S. and Coskun, S. (2005) Application of the Finite Element Method to Gravity Data Case Study: Western Turkey. Journal of Geodynamics, 39, 431-443. https://doi.org/10.1016/j.jog.2005.04.003

[42] Ndougsa-Mbarga, T., Bikoro-Bi-Alou, M., Tabod, T.C. and Kant-Sharma, K. (2013) Filtering of Gravity and Magnetic Anomalies Using the Finite Element Approach (FEA). Journal of Indian Geophysical Union, 17, 167-178.

[43] Bihiya, W., Ndougsa, M.T., Yene-Atangana, Q., Ngoumou, P.C. and Tabod, T.C. (2013) 2.5D Models Derived from the Magnetic Anomalies Obtained by Upwards Continuation in the Mimbi Area, Southern Cameroon. Journal of Earth Sciences and Geotechnical Engineering, 3, 175-199.

[44] Bikoro-Bi-Alou, M., Ndougsa, M.T. and Tabod, T.C. (2014) Quantitative Interpretation of Magnetic Anomalies in Ebolowa-Djoum Area (Southern Cameroon). Geophysica, 50, 11-25.

[45] Zanga Amougou, A., Ndougsa Mbarga, T., Meying. A., Layu Yufenyu. D., Bikoro Bi Alou. M. and Manguelle Dicoum, E. (2013) 2.5D Modeling of Crustal Structures along the Eastern Cameroon and Western Central African Republic Derived from Finite Element and Spectral Analysis Methods. Geophysica, 49, 75-97.

[46] Tadjou, J.M., Nouayou, R., Kamguia, J., Kande, H.L. and Manguelle-Dicoum, E. (2009) Gravity Analysis of the Boundary between the Congo Craton and the Pan-African Belt of Cameroon. Austrian Journal of Earth Sciences, 102, 71-79.

[47] Shandini, N.Y., Tadjou, J.M., Tabod, C.T. and Fairhead, J.D. (2010) Gravity Data Interpretation in the Northern Edge of the Congo Craton, South-Cameroon. Anuário do Instituto de Geociências, 33, 73-82.

[48] Radhakrisna Murty, I.V. and Krishnamacharyulu, S.K.G. (1990) Polyfit: A Fortran-77 Program to Fit a Polynomial of Any Order to Potential Field Anomalies. Journal of Association of Exploration Geophysicists, 11, 99-105.

[49] Franke, R. (1982) Scattered Interpolation: Test of Some Methods. Mathematics of 
Computation, 38, 184-200. https://doi.org/10.2307/2007474

[50] Telford, W.M., Geldart, L.P., Sherriff, R.E. and Keys, D.A. (1990) Applied Geophysics. Cambridge University Press, Cambridge, 860 p.

[51] Neumann, R. (1973) Prospection gravimétrique: In traité de géophysique interne. Masson, Paris, 613-620.

[52] Integrated Geophysics Corporation (2002) Bouguer Gravity Maps Identify Regional Basin Structure and Resultant Preferred Directions of Lateral Oil and Gas Migration. IGC Footnotes Series on Interpretation, 3, 1-6.

[53] Spector, A. and Grant, F.S. (1970) Statistical Models for Interpreting Aeromagnetic Data. Geophysics, 35, 293-302.

[54] Gerard, A. and Debeglia, N. (1975) Automatic Three-Dimensional Modelling for Interpretation of Gravity or Magnetic Anomalies. Geophysics, 40, 1014-1034.

[55] Bhattacharryya, B.K. and Leu, L.-K. (1975) Spectral Analysis of Gravity and Magnetic Anomalies Due to Two-Dimensional Structures. Geophysics, 40, 993-1013.

[56] Bhattacharyya, B. K. and Leu, L.-K. (1977) Spectral Analysis of Gravity and Magnetic Anomalies Due to Rectangular Prismatic Bodies. Geophysics, 42, 41-50.

[57] Boukeke, D.B. (1994) Structures crustales d'Afrique centrale déduite des anomalies gravimétriques et magnétiques: le domaine précambrien de la République Centrafricaine et du Sud-Cameroun. Thèse de Doctorat, université de Paris Sud, 264 p.

[58] Nnange, J.M., Ngako, V., Fairhead , J.D. and Ebinger, C.J. (2000) Depths to Density Discontinuities Beneath the Adamawa Plateau Region, Central Africa, from Spectral Analysis of New and Existing Gravity Data. Journal of African Earth Sciences, 30, 887-901. https://doi.org/10.1016/S0899-5362(00)00058-0

[59] Nguimbous-Kouoh, J.J., Ndougsa-Mbarga, T., Njandjock-Nouck, P., Eyike, A., Campos-Enriquez, J.O. and Manguelle-Dicoum, E. (2010) The Structure of the Goulfey-Tourba Sedimentary Basin (Chad-Cameroon): A Gravity Study. Geofísica Internacional, 49, 181-193.

[60] Pal, P.C., Khurana, K.K. and Unnikrishnan, P. (1978) Two Examples of Spectral Approach to Source Depth Estimation in Gravity and Magnetic. Pure and Applied Geophysics, 117, 772-783. https://doi.org/10.1007/BF00879978

[61] Basseka, C.A., Shandini, Y.N. and Tadjou, J.M. (2011) Subsurface Structural Mapping Using Gravity Data of the Northern Edge of the Congo Craton, South Cameroon. Geofizika, 28, 231-244

[62] Mapoka, H., Danguene, E.Y., Prince Nzenti, J.P., Biandja, J., Kankeu, B. and Suh, C.E. (2011) Major Structural Features and the Tectonic Evolution of the Bossangoa-Bossembele Basement, North Western Central African Republic. The Open Geology Journal, 5, 21-32. https://doi.org/10.2174/1874262901105010021

[63] Cooper, G.R.J. (2003) Grav2dc 2.10 for Microsoft Windows. 